\title{
CREATIVE PERIPHERY SYNDROME? OPPORTUNITIES FOR SUSTAINABLE TOURISM INNOVATION IN TIMOR-LESTE, AN EARLY STAGE DESTINATION
}

\author{
David Weaver \\ Department of Tourism, Sport and Hotel Management, Griffith University, Australia \\ Email: d.weaver@griffith.edu.au
}

\begin{abstract}
The lack of tourism development in Timor-Leste can be situated as an opportunity to build "from scratch" an innovative and sustainable tourism sector that capitalises on the advantages of peripherality, including amenability to peak experiences, tourism centrality, opportunistic innovation, optimal autonomy, and cultural/natural distinctiveness. As such, peripherality is positioned as a negotiable and negotiated construct. A resultant spatial framework for strategic development, in tandem with the principles of enlightened mass tourism, features tourism sub-systems with core growth poles, cultural hinterlands with community-responsive tourism, and nature-based hinterlands, both terrestrial and marine, that emphasise visitor participation in site enhancement. These initiatives can inform sustainable tourism development in other incipient destinations or be used to recalibrate tourism in moredeveloped destinations.
\end{abstract}

Key words: Timor-Leste, small islands, peripherality, sustainable tourism, tourism planning 


\section{INTRODUCTION}

During the contemporary era of exponential tourism growth that commenced in the 1950s, small island states have emerged as sites of exceptionally high leisure tourism activity relative to their land area and resident population (Carlsen \& Butler, 2011; Conlin \& Baum, 1995; Modica \& Uysal, 2016). Timor-Leste, however, with its negligible and chronically low-traction tourism sector (Tolkach, 2017), stands out as an anomaly within this group of highly “destinationised” geopolitical entities. This may be interpreted by some as both a consequence and indication of the country's poor prospects for development as a tourist destination, for reasons largely associated with its multiple peripheralities. A concern is that such perceptions may become self-fulfilling if they promote the low prioritisation of tourism in national development strategies relative to, for example, agriculture, mining and manufacturing.

An alternative and less intuitive perspective positively situates Timor-Leste as a "tabula rasa” upon which an essentially new, highly innovative and comprehensively sustainable tourism sector can be realistically imagined and implemented. Sustainabilityrelated goals and objectives should be integrated into tourism planning and policy from the earliest stages of tourism development if they are to have a good chance of being realised, and Timor-Leste offers a good possibility for doing just that. Subsequently, its tourism sector could serve as a model for other highly peripheralised destinations at similarly incipient - or even more articulated - stages of tourism-related development. Such imaginings of a “creative periphery syndrome” certainly requires attention to the "poor prospect” argument that dominated the small island economic literature before the 1990s (Prasad, 2009), but the focus in this paper is on the demerits of that perspective and the concomitant merits of this alternative perspective of Timor-Leste as a potential model of sustainable global innovation, based on the increasingly accepted premise of peripherality as opportunity and strength rather than just threat and weakness. The applicability of recent innovations in the area of sustainable tourism, in this reimagined context, is also explored, since the attendant opportunities and strengths will prevail as such only if they promote the "triple bottom line" of environmental, economic and socio-cultural sustainability (Elkington, 1997). 


\section{LITERATURE REVIEW}

\subsection{The Little Giants of Tourism}

The post-World War Two demand for leisure tourism inordinately favoured temperate and sub-tropical coastlines and islands because of their ample "3S" (sea, sand, sun) assets. Affiliated pull factors have included geographical proximity to major market regions, increased infrastructural accessibility, colonial status which facilitated investment and tourist entry during formative stages of tourism development, affordability, and overall perceptions of peace, stability and safety (Weaver \& Lawton, 2014). Although problematised by Turner and Ash (1975) as components of a "pleasure periphery" where the inequitable coreperiphery relationships of an earlier plantation era are perpetuated, there is little question that small island states - otherwise seemingly bereft of competitive advantage compared with other settings - have been very successful in fostering economies dominated by 3S tourism. The 50 small island states and dependencies that report tourism arrival data to the UNWTO, as a group, account for just $0.185 \%$ of the global land mass and $0.36 \%$ of global population, but $4.2 \%$ of all stayover (overnight) international tourist arrivals, and fully $54.8 \%$ of all excursionist arrivals from cruises originating in foreign ports (UNWTO, 2016). Of the 26 entities (mostly independent states) that also report inbound tourism revenue relative to GDP (Table 1), an average contribution of $20.8 \%$ is noted, with 19 displaying contribution levels of $10 \%$ or higher.

$<$ Table 1 here $>$

Most dependencies do not report this statistic, but very high contributions can also confidently be attributed to such applicable destinations as Bermuda, British Virgin Islands, Cayman Islands, Cook Islands, Curacao, Guadeloupe, Guam, Martinique, Palau, Sint Maarten, Turks \& Caicos Islands, and the US Virgin Islands. Non-sovereign or nondependency entities that further attest to the relative importance of islands as leisure tourist destinations include Jeju (South Korea), Phuket (Thailand), Langkawi (Malaysia), Bali (Indonesia), Hainan (China), the Balearics and Canaries (Spain), Rhodes (Greece), Hawai'i (USA), Margarita (Venezuela), Zanzibar (Tanzania), Djerba (Tunisia), and Qeshm (Iran).

\subsection{Timor-Leste as Anomaly}

Against such impressive collective performance, the $0.4 \%$ contribution of TimorLeste stands out as an extreme outlier, well below even the $2.8 \%$ of Trinidad and Tobago, its 
nearest rival for salient tourism under-performance. Projected as a social phenomenon, the 50 island states and dependencies accommodate, on a per annum average, about two international stayover tourists for every permanent resident; in the case of Timor-Leste, it is about one visitor for every 20 permanent residents, or a 40-fold under-representation in the guest-to-host ratio. As of 2013, just 18 "hotels and similar establishments" were reported for the entire country, accommodating 24,000 guests and just 94,000 visitor-nights (UNWTO, 2016).

One way of understanding this meagre performance is to consider in some logical sequence the weakness of critical pull factors that normally facilitate robust tourism performance. First, potential visitors must have knowledge that the destination exists and a positive image which merits the presence of that destination on their list of potential places to visit. Timor-Leste languished initially as an obscure colonial backwater of Portugal for four centuries, geographers and philatelists being among the few even aware of its existence. The 1975 invasion by Indonesia generated further awareness though in a negative way through subsequent associations with political violence and oppression while as an independent state there is evidence of a partial return to obscurity as well as lingering perceptions of instability. This is due at least partially to its location within Australia's supposed northern "arc of instability” (Rumley, Forbes \& Griffin, 2006), and continued exhortations from the Australian government, like other governments, for Australian visitors to "exercise a high degree of caution” whilst there.

For those who graduate through the perceptual barrier, considerations of destination accessibility implicate a second filter or barrier - is it convenient to get there? Four centuries of neglectful Portuguese colonialism were endured in classic core/periphery terms while subsequent Indonesian control witnessed its double exploitation as the "periphery of a periphery” (Weaver, 1998). In both cases, investments in internal and external infrastructure were minimal so that connectivity with the outside world, and within the country, remains incipient (Tolkach, 2017; Tolkach \& King, 2017). The prospect of three or more separate flights to reach the small airport in Dili, accordingly, dissuades many potential visitors. For those not yet dissuaded, a third barrier of trip affordability must be negotiated. Here, Rajalingam (2014) notes that it was nearly twice as expensive to travel from Sydney to Dili in 2014 as it was to fly to Papua New Guinea. Once inside the country, survey results from the same author indicated low visitor satisfaction with the transport network, so that gaining access to attractions beyond Dili and its immediate surrounds remains a persistent challenge. More generally, the apparatus of government is relatively unstable and inefficient, and 
therefore poorly positioned to devise and implement national and sector-specific development plans that facilitate successful tourism visits (Tolkach, 2017).

\section{METHOD}

This study is based on the premise that the current lack of tourism development in Timor-Leste provides an invaluable opportunity to build an innovative, sustainable, and successful industry effectively unencumbered by existing incipient patterns and structures of tourism articulation. A case study approach is used because it provides focused and deep engagement with a relevant real world setting using multiple methods as warranted (Jennings, 2010), and is especially appropriate where the topic is exploratory but potentially applicable to other places (Beeton, 2005). The promise of the case study in this regard is subsequently considered from the unconventional perspective that small-island peripherality confers at least as many potential advantages as disadvantages. These advantages are conveyed through a series of incongruities identified by Weaver (2016) that allow the advantageous elements to be distilled and ultimately applied within the spatial context of a hypothetical broad national strategic framework which additionally incorporates selective theoretical elements of contemporary sustainable tourism thought that complement and accommodate those advantages. It is hoped that this framework and its attendant discussion can offer a compelling basis for follow-up engagement - in tandem with an appropriate "action research" agenda (Brydon-Miller, Greenwood \& Maguire, 2003) - with both the broad and destinationspecific challenges of realising sustainable tourism development in Timor-Leste, similar early-stage tourist destinations in the developing world and elsewhere, and within more established destinations seeking to realign or augment their tourism development strategies.

\section{FINDINGS}

\subsection{Timor-Leste as Tourism Exemplar?}

Notwithstanding the very serious impediments described above, the tourism situation for Timor-Leste is not entirely negative even in its current early manifestation. For example, those who do visit after successfully negotiating the aforementioned sequential barriers of perception, physical accessibility and trip affordability report high satisfaction with the country's natural and cultural attractions and with the affordability of local prices (Rajalingam, 2014). Promisingly, in the latter survey there was very high agreement that the visit met expectations (83\%) and consequent very high willingness (79\%) to recommend Timor-Leste to friends and family as a destination. The current strategic development plan for 
the country (Timor-Leste, nd) recognises this tourism potential and admirably (if conventionally) seeks to realise this potential by way of a low volume, high yield sector that avoids mass tourism markets and promotes "authentic tourist offerings" through niche products such as ecotourism, marine tourism, historical and cultural tourism, adventure and sport tourism, and religious and pilgrimage tourism. Related objectives include economic diversification, the creation of durable employment opportunities for a relatively low-skilled labour force, increased capacity to accommodate tourists, and the geographical diffusion of tourism-related economic benefits. Collaboration with the private sector is encouraged, and support is to be given to local communities to increase their capacity as tourist service providers and primary recipients of tourist-generated revenue.

\subsection{Peripherality as strength and opportunity}

This national strategic plan repeatedly emphasises the challenges associated with Timor-Leste's multiple (geographical, economic, political) peripheralities. This is appropriate, though the inherent potential benefits and opportunities of peripherality should be taken into consideration as well. Weaver (2016) presents five interrelated "paradoxes" associated with peripheral small islands which collectively if counter-intuitively constitute a “creative periphery syndrome”. The status of each as a genuine paradox is disputed (Butler, in press), so they are considered here as tentative "incongruities" requiring further articulation.

\section{Geographic periphery \& experiential core}

First, they are a type of geographic periphery, but simultaneously an experiential core (Weaver, 2013). Small tropical islands have long been romanticised as treasure islands and, more recently, pleasure-leisure islands (Lockhart, 1997), and stressed visitors escaping the weather and work demands of cooler climates have ample opportunity to experience relaxation, delight, even bliss, in these physically and psychologically isolated destinations. Weaver and Lawton (2017) evoke similar emotive powers, albeit implicating different emotions, to Greenland, an extreme type of insular peripherality. Recent interest in ecotourism adds possibilities of awe and inspiration, especially given the advantages of islands in featuring charismatic endemic fauna and flora (Halpenny, 2001). Opposite sentiments such as melancholy, contemplation, loneliness and sadness may also attend the visitor's experience of dark tourism sites, with islands often seen by perpetrators as places 
where atrocities can be hidden or enemies kept out of trouble and sight (Strange \& Kempa, 2003).

The diversity of Timor-Leste's natural, cultural and historical resources indicates the possibilities of a rich and memorable experiential tableau that can satisfy the spectrum of visitor motivations and induce repeat visitations as well as recommendations. As described by Tolkach (2017), these unexploited and underexploited tourist attractions include high biodiversity and endemic terrestrial and marine flora and fauna, dramatic mountain vistas, diverse traditional cultures and lifestyles, colonial era architecture and atrocity sites, and remote beaches.

\section{Economic marginality \& tourism centrality}

The second incongruity is that overall economic marginality is accompanied by tourism centrality. Just as large urban areas are advantaged as economic cores that attract migrants, small warm-water islands are advantaged as experiential cores that attract leisure visitors seeking affective stimulation. The articulation of this competitive advantage into fullfledged 3S tourism sectors is best expressed in places such as the Maldives, Aruba and Anguilla, where "next-best" traditional primary sectors such as agriculture and fishing languish embarrassingly behind. Though widely criticised as embodying "plantation models" of tourism that maintain inequitable core-periphery relationships and monocultures under different guise (Weaver, 1988), others such as Croes (2006) emphasise how tourism overcomes size constraints and generates economies of scale in a context that normally imposes diseconomies of scale on most other sectors. Undoubtedly, and notwithstanding questions of volatility and distribution, tourism has proven itself to be an effective generator of employment and revenue in a context otherwise ill-favoured for sustained economic development. And again with similar caveats, it has also been demonstrated that residents of small islands are in general positively inclined toward tourism development, whether those islands are relatively wealthy or poor, and tourism-incipient or tourism-mature (Akis, Peristianis \& Warner, 1996; Nunkoo \& Ramkissoon, 2010; Ribeiro, Valle \& Silva, 2013; Shakeela \& Weaver, 2012).

Timor-Leste does not currently project this incongruity due to its incipient stage of tourism development, but an aspirational and realistic potential contribution of tourism to GDP is probably in the $10-15 \%$ bracket, somewhat below the $21 \%$ average (Table 1 ) due to the skewing effects of the dominant petroleum sector. Inhibiting factors include the lack of appropriate tourism-related education and training, government instability, the short-term 
character of international projects, lack of coordination and interest articulation within the small private tourism sector, and the crude state of national roads and other critical infrastructure (Tolkich, 2017).

\section{Tourism monoculture \& opportunistic innovation}

Monoculture-like leisure tourism sectors in many small island states belie the status of such entities as arenas of opportunistic innovation. This third incongruity holds that the paucity of conventional resource endowments necessitates economic creativity, adaptability and resilience (Baldacchino, 1993; Connell, 2007). The disproportionate importance of small islands as tax havens and financial centres is a major manifestation of this phenomenon (Dharmapala \& Hines, 2009), but also germane are the issuance of superfluous postage stamps for the philatelic market and flags of convenience for the shipping industry (Wood, 2000), and - of additional concern - the hosting of online gaming or pornography sites (Jackson, 2012) and provision of economic citizenship-of-convenience schemes (Van Fossen, 2007a). Innovation can also be demonstrated within tourism itself, as evidenced by early attempts in Dominica to promote the island as an ecotourism destination (the "Nature Island of the Caribbean”) as an apparently opportunistic response to its lack of white sand beaches and reliably sunny weather (Weaver, 1991, 2004).

The challenge for Timor-Leste is to devise an appropriate array of innovative strategies both within and external to tourism that will collectively help to realise a sustainable and competitive economy. Inhibiting such efforts, however, is a dominant petroleum sector that suppresses the need for innovation, encourages potentially inappropriate and high-cost mega-projects, disadvantages small-scale entrepreneurship, and cultivates a complacent and corrupt elite class as per "resource curse” theory (Auty, 2002; Ross, 2012). Such factors may underlie current government plans to establish a special US\$4 billion economic zone and associated mega-resort in the enclave of Oecusse (Yoder, 2015), a double-periphery similar to Barbuda or Tobago, despite its incompatibility with the aspirations for smaller scale tourism expressed in the current national development strategy (Timor-Leste, nd).

\section{Geopolitical dependency \& optimal autonomy}

The fourth incongruity juxtaposes a syndrome of geopolitical dependency with the realisation of optimal autonomy. Described by Baldacchino (1993) as the "power of being powerless”, this emphasises the unexpectedly high levels of agency and leverage that are 
typically exercised by small island stakeholders who are no longer existentially threatened by their supposedly oppressive overlords in the core regions or larger neighbours. According to Baldacchino (2012), “smallness, often accompanied by islandness, low/no populations and relative isolation, facilitates the room for imaginative and strategic manoeuvre (p. 236)”. A good illustration is the ability of entities such as the Cayman Islands to retain major advantages of dependency status (e.g. UK remaining responsible for defence and foreign relations) while concurrently enjoying considerable local autonomy (e.g. profiting from tax haven status). For Micronesia, Marshall Islands and Palau, sovereignty is qualified by the retention of numerous privileges associated with their former status as US dependencies (Levine \& Roberts, 2005).

For such sovereign states, geopolitical leverage is gained individually and collectively through the principle of sovereign equality, where the latter has the same voting power as China in the UN General Assembly and other peak international bodies. Lobby groups such as the Alliance of Small Island States, with 39 members (AOSIS, 2017) may eventually come to include tourism as an item of negotiation (especially as the latter's fortunes are tied to the current emphasis on global warming). Until then, small states can play the game of "dollar diplomacy” (Van Fossen, 2007b), wherein recognition of a mainland China over a Taiwan becomes a question of which of those two countries is prepared to make the best airport upgrade or send in the most tourists. Capacities for Baldacchino's imaginative and strategic manoeuvre have also been demonstrated by Timor-Leste in its robust and aggressive negotiations with Australia over their common maritime boundary in the petroleum-rich Timor Sea (Allard, 2016). Concurrently, mutually advantageous ties have been strengthened with China as part of a strategy of cultivating “many international friends” (Hutt, 2016).

\section{Homogenised tourism \& cultural-ecological distinctiveness}

The fifth incongruity is the discrepancy between the apparent status of small island tourism as an increasingly homogenised-globalised-standardised-substitutable product, and apparent broader tendencies toward increased cultural and ecological distinctiveness. Just as earlier encounters with other cultures usually led to the selective absorption of external traits rather than the extinction of local culture (Baldacchino, 2005), contemporary tourism also adds its often positive contributions to the latter; Canavan (2016) even suggests the creation of new "tourism cultures" embodying the mutually beneficial interaction and crossacculturation between hosts and guests. The apparent empowerment of local residents in such interactions is reinforced by the tendency of tourism to be very highly concentrated in a few 
strategically located gateway, beachhead and attraction-icon locations (Weaver \& Lawton, 2014), often as resort and residential enclaves (Freitag, 1994), so that elsewhere locals are by far the dominant human presence and landscape influence. Of great relevance here as well is the allegedly increasing proclivity of tourists to search for "authenticity”, expressed otherwise as the "sense of place" that makes one destination distinct from any other (Derrett, 2003). Already endowed with substantial endemic animals and plants as well as distinctive if hybridised cultures, the implication is that the small island's competitiveness as a destination will increase to the extent that the positive aspects of this cultural and natural diversity are amplified through the appropriate development and marketing of local tourist attractions that respect unique and interesting local cultural traditions (Palmer \& Carvalho, 2008).

\subsection{Broad strategic considerations}

This recalibration of peripherality as a strength and opportunity, and hence a negotiable and negotiated construct that evokes a creative periphery syndrome, needs to be contextualised within a broader strategic framework for the tourism sector of Timor-Leste. One focal possibility is the concept of “enlightened mass tourism”, proposed by Weaver (2014) as a synthesis of mass tourism and alternative tourism arising as the logical culmination of increasing interaction and inter-digitation between these two sectors since the 1990s. The logic is that all tourism, including so-called "niche” and "alternative” tourism, is essentially connected to a single global - or mass - tourism sector, most evident in the reality that even the most dedicated alternative tourist will require passage on a major airline and financial transactions through major banks and credit card companies as conditions of visiting remote “community-based” destinations in the Amazon or Sahara (Pearce, 1992). Beyond this necessity, mass tourism also has inherent advantages such as economies of scale and global connectivity that are conducive to achieving sustainable outcomes. However, recognising that unregulated mass tourism can have numerous environmental, economic and socio-cultural costs (Buckley, 2004; Cole \& Morgan, 2010; Mathieson \& Wall, 2006), the necessary "enlightened" component of this mass tourism reality arises from the deliberate injection of desirable alternative tourism principles such as the ethical imperative, a community focus, and an emphasis on destination sense of place. Weaver (2014) proposes resolution-based dialectics as a suitable approach for distilling and amalgamating the positive aspects of mass and alternative tourism within specific destination contexts.

Contentiously, Weaver (2012) suggests that all forms of contemporary tourism are evolving toward what can now be styled as enlightened mass tourism. For stereotypical over- 
developed beach resorts such as Waikiki and Magaluf, this is alleged to develop along an "organic" trajectory wherein crises associated with breached destination carrying capacities necessitate public and private sector decisions which ultimately restore these destinations to a state of equilibrium. Such a scenario is irrelevant to Timor-Leste because of the incipient state of its tourism industry, but two other proposed scenarios are critically important to the realisation of enlightened mass tourism in that country. First, it is sensible, in the manner of Mexico in the 1960s (Torres \& Momsen, 2005), that advantageously endowed and located growth poles be designated as nodes for relatively intensive 3S tourism development. In these select locations, an "induced" trajectory to enlightened mass tourism means that the principles and best practice of sustainable tourism are integrated into all stages of growth pole planning, development and management. For other parts of the country, an "incremental" trajectory should pertain wherein tourism development begins at a small scale suggestive of “deliberate alternative tourism” (Weaver, 1991). Local carrying capacity, whether in a village or protected area, can then be increased to gradually accommodate prevailing levels of demand. As these levels vary from place to place, only certain locations will experience appreciable intensification of their tourism sectors.

A hypothetical spatial application of these ideas is provided in Figure 1. Initially, the status of Dili as a viable international gateway (A) must be assured so that a critical mass of inbound tourists can gradually be generated to justify and ephemerally populate the proposed tourism landscape. It is necessary therefore to overcome the perceptual, accessibility and affordability barriers to visitation described earlier. Overcoming the key perceptual barrier requires sustained creative marketing to overcome images of obscurity, instability, inconvenience and pervasive poverty. Existing visitors should be mobilised as touristmarketers, and local people as resident-marketers, to convey positive “organic” images to the outside world through diverse social media, which are regarded by most consumers as more credible than the "induced" (and more expensive) image projections of destination marketing organisations and tourism corporations (Mangold \& Faulds, 2009). Indonesia, Australia, China and Portugal constitute a logical "front four" in which to focus initial marketing efforts, though an argument could be made for including the Philippines in a reconstituted "front five” given its spatial proximity, cultural similarities (e.g. Roman Catholic majority), robust economic growth, and large population (over 100 million). In 2014, over US\$12 billion in expenditures were made by outbound Philippines residents (UNWTO, 2016). 
The next element of the hypothetical Timor-Leste tourism-scape is the establishment of two or three beach- and marine-based tourism resort growth poles (B) which will stand out internationally, as per the aforementioned induced path to enlightened mass tourism, for their cutting-edge environmental technologies and progressive social initiatives. A more modest and place-conscientious version of the proposed special economic zone in the Oecusse enclave described by Yoder (2015) may be appropriate (see above). Constituent elements could include:

- dominance of alternative energy technology in hotels and other buildings

- integration of local architectural style into building design

- maximum fresh water efficiency

- Blue Flag certification for local beaches

- local biodiversity reflected in landscaping, green roofs and public parks

- alternative energy public transit for local transportation of tourists and locals

- maximum local and national sourcing of goods and services

- incorporation of traditional land tenure arrangements

These growth poles ideally would be connected by a high quality coastal trunk road constructed to service the national economy and society as a whole. The settled and mostly agricultural areas adjacent to the growth poles are designated as (C) in this model, and the offshore zone and mountainous interior both as (D); all three spaces are subject to the incremental trajectory described above, though the first from a mainly cultural and the latter two from a mainly natural perspective.

It is perhaps more useful to further describe (C) and (D) as to how they can relate to the growth poles, since to have these designated over the entire territory is to spread the development effort too thinly (although some tourists may still choose to visit these “informal” areas). Each growth pole can be considered as a type of secondary or internal gateway (Dili is the primary or external gateway) with its own localised functionally integrated (C) \& (D) "hinterland” (Povilanskas \& Armaitienè, 2011). To illustrate, it would be normal for a resort stayover on a 7-day holiday, beyond activity at the beach and in the resort complex, to spend time (a) on the water visiting a coral reef or whale watching, (b) in a local village and historical attractions, and (c) in a protected area in the mountainous interior, the land components connected to the growth pole by improved secondary roads. Each 
combination of (D-marine)-(B)-(C)-(D-mountain) thus constitutes a localised tourism subsystem within the national tourism system, although this of course does not preclude movement of tourists between sub-systems.

For zones (C) and (D) in general, various innovations can be considered. Settled agricultural areas (C), for example, appear to be logical venues for what is broadly endorsed as community-based tourism (CBT) premised on empowering local people through their active control over the small-scale "alternative" tourism that is fostered at the village level. Though accepted as orthodoxy by many major international development agencies and other proponents of sustainable rural development, including in Timor-Leste itself (Tolkach \& King, 2015), CBT is alleged by others to have a questionable record of success (Buckley, 2003; Salafsky et al, 2001) due to factors such as persisting financial dependency on outside development agencies (Zeppel, 2006), inequitable internal distribution of costs and benefits (Medina, 2005) and low market response due to problems of physical accessibility and awareness. Indeed, Tolkach and King (2015) regard contemporary efforts to promote CBT in Timor-Leste by government and various NGOs as uncoordinated, largely unsuccessful, and more a matter of aspiration and potential than reality.

More in tandem with the globalised and systematic nature of tourism, according to Weaver (2010), is community-responsive "partnership-based tourism” that focuses on achieving meritorious community goals such as higher quality of life and happiness. With conventional (unregulated) mass tourism and CBT occupying unsustainable poles of the political spectrum, community-responsive options seek a middle ground of meaningful community consultation and opportunities for participation, in partnership with external stakeholders from the private and public sectors. As with enlightened mass tourism, resolution-based dialectics offer a destination-specific approach to identifying a sustainable synthesis between the two polarities.

A promising innovation for the more remote and mountainous zone (D) as well as its offshore marine equivalent, is the "ecotourium” (Fennell \& Weaver, 2005). This has been proposed as a parallel designation for existing protected areas in which the existing planning and management mandate is expanded to utilise the potential of visitors to act directly and indirectly as agents of biodiversity enhancement within and adjacent to park boundaries. The term combines the words ecotourism and auditorium to suggest a venue where visitors are "on stage" to achieve objectives associated with activist ecotourism through for example direct participation in tree planting and weed removal, citizen-based scientific research (e.g. bird or fish surveys) and development of interpretive material, and indirect participation in 
giving donations and purchasing goods from which a portion of receipts are devoted to park biodiversity enhancement. Although the ecotourium exists currently only as a concept, Timor-Leste has both the need and opportunity to establish prototypes. The need acknowledges that the country's forest cover declined by 30\% between 1972 and 1999 and that only $1-6 \%$ of the remaining $35 \%$ under some kind of forest cover consists of highdiversity primary forest (Timor-Leste, 2011). The opportunity is that the country's 30 terrestrial protected areas now require major reform to move beyond their status as largely "paper parks" (Bonham, Sacayon \& Tzi, 2008) that neither adequately fulfil their mandate to protect the local biodiversity nor yet attract a significant number of tourists.

A related issue is the distinction between local sustainability-related impacts such as congestion and water pollution, and global impacts such as climate change, which Høyer (2000) respectively regards as having distinct but interrelated "intensity" and "volume” dimensions. Carbon emissions and other volume impacts are inevitable by-products of all tourism activity, implicated mainly in the transit process, but these can be minimised to some extent in the proposed model through the inclusion of enhancement measures that restore native carbon sinks. The focus on short- and medium-haul regional markets such as Australia, Indonesia and the Philippines, in addition, would result in lower per capita visitor emission outputs. Another important issue, innovative proclivities and enthusiasm aside, focuses on national and local capacity to implement such a strategy. Recent empirical research by Vong, Silva and Pinto (2015) revealed among local public and private sector leaders in Timor-Leste strong rhetorical support for the concept of sustainable development and understanding of underlying motives for its pursuit, but limited access to relevant knowledge or adoption of sustainable practices, and widespread recognition of the barriers to implementation. NGO leaders, however, had much higher awareness and participation, and hence potential to take a lead role in sustainability initiatives.

Finally, a note of caution is merited in that the same innovation proclivities that favour the proposed tourism strategy also favour other tourism and non-tourism initiatives that may be incompatible with the latter, especially if they present as compelling "quick fixes” that promise to address entrenched economic problems. As of 2017, land acquisitions and initial constructions were underway in the Oecusse special economic zone, generating considerable ambivalence among residents as to the actual benefits that are and will be derived (Davidson, 2017). Rumours of a similar type of development on the offshore island of Atauro have generated similar concerns, with many residents allegedly preferring smaller 
scale tourism options that privilege local businesses, culture and natural environment (James, 2017), as per the desired trajectory outlined in the national development strategy.

\section{CONCLUSION}

While fully acknowledging the associated challenges and weaknesses of tourism development in Timor-Leste, the primary message of this research is to emphasise the country's potential as an "arena of opportunity" for creative - and world-leading - innovation in sustainable tourism management, an opportunity enabled by its relative tourism incipience. Inspired and enabled by a reimagining of peripheral small islands as settings for peak experiences, creative economies, robust tourism sectors, optimal autonomy and increased distinctiveness, and focused on the broad objective of enlightened mass tourism, a strategy for tourism development is proposed to augment existing aspirational emphases on infrastructural and human capacity enhancement. The first element is the implementation of a marketing campaign that creates positive awareness of the country's possibilities for providing visitors with peak emotional experiences, as conveyed by the social media accounts of actual visitors. Second, subsequent increased demand especially from the "front five" tourist markets rationalises the establishment of two or three beach-centred resort growth poles that feature best practice environmental and social sustainability as per the “induced" path to enlightened mass tourism. Third, each growth pole is surrounded by a settled agricultural hinterland which receives excursionist and stayover visitors from the coastal resorts through community-responsive tourism that synthesises the best elements of conventional mass tourism and community-based tourism. Fourth, the protected areas in the mountainous extremities of these hinterlands are proposed as prototype ecotouriums in which those same visitors serve as active agents of biodiversity enhancement - a role that fundamentally moves them from a conventional perspective of biodiversity threat to one of biodiversity opportunity.

It is speculated that such innovations, engaged and modified as warranted through an action research agenda that emphasises full community participation and practical solutions to "real world" problems, can position Timor-Leste as a global leader in sustainable tourism development that makes a substantial and well-integrated contribution to the nation. The results and implications, however, are not confined to highly peripheralised or tourismincipient destinations alone. The strategy, or specific elements thereof, also provides recalibration opportunities for destinations at higher stages of tourism development. For example, many Caribbean and South Pacific islands have well-articulated concentrations of 
coastal resort development but unintegrated hinterlands that serve as little more than impoverished labour reservoirs for the latter. Community-responsive near hinterlands and ecotourism-focused far hinterlands are feasible strategies for such locations that may help to stimulate an organic path to sustainability for the parent coastal resorts. A broader outcome of comprehensive sustainability is therefore envisaged from these proposals.

\section{REFERENCES}

Akis, S., Peristianis, N., Warner, J. (1996). Residents’ attitudes to tourism development: The case of Cyprus. Tourism Management, 17, 481-494.

Allard, T. (2016). East Timor takes Australia to UN over sea border. Sydney Morning Herald, April 11. Accessed at http://www.smh.com.au/federal-politics/politicalnews/east-timor-takes-australia-to-un-over-sea-border-20160411-go39tl.html.

AOSIS (2017). Alliance of Small Island States. Accessed at http://aosis.org/.

Auty, R. (2002). Sustaining Development in Mineral Economies: The Resource Curse Thesis. London: Routledge.

Baldacchino, G. (1993). Bursting the bubble: The pseudo-development strategies of microstates. Development and Change, 24, 29-52.

Baldacchino, G. (2005). Islands - objects of representation. Geografiska Annaler, 87B, 247251.

Baldacchino, G. (2012). Governmentality is all the rage: The strategy games of small jurisdictions. The Round Table, 101, 235-251.

Beeton, S. The case study in tourism research: A multi-method case study approach. In Ritchie, B.W., Burns, P. \& Palmer, C. (Eds.), Tourism Research Methods: Integrating Theory with Practice. Oxfordshire: CABI, pp. 37-48.

Bonham, C., Sacayon, E., \& Tzi, E. (2008). Protecting imperiled “paper parks”: Potential lessons from the Sierra Chinajá, Guatemala. Biodiversity Conservation, 17, 1581-1593.

Brydon-Miller, M., Greenwood, D., \& Maguire, P. (2003). Why action research? Action Research, 1, 9-28.

Buckley, R. (2003). Case Studies in Ecotourism. Wallingford, UK: CABI.

Buckley, R. (2004). Environmental Impacts of Tourism. Wallingford, UK: CABI.

Butler, R.W. (in press).

Canavan, B. (2016). Tourism culture: Nexus, characteristics, context and sustainability. Tourism Management, 53, 229-243. 
Carlsen, J. \& Butler, R. Eds. (2011). Island Tourism: Sustainable Perspectives. Wallingford: CABI.

Cole, S. \& Morgan, N. Eds. (2010). Tourism and Inequality: Problems and Prospects. Wallingford, UK: CABI.

Conlin, M. \& Baum, T. Eds. (1995). Island Tourism: Management Principles and Practice. Chichester: Wiley.

Connell, J. (2007). Islands, idylls and the detours of development. Singapore Journal of Tropical Geography, 28, 116-135.

Croes, R. (2006). A paradigm shift to a new strategy for small island economies: Embracing demand side economics for value enhancement and long term economic stability. Tourism Management, 27, 453-465.

Davidson, H. (2017). Timor-Leste's big spending: A brave way to tackle economic crisis or just reckless? Theguardian. May 25. Accessed at https://www.theguardian.com/world/2017/may/25/timor-leste-spending-big-economiccrisis.

Derrett, R. (2003). Making sense of how festivals demonstrate a community’s sense of place. Event Management, 8, 49-58.

Dharmapala, D. \& Hines, J. (2009). Which countries become tax havens? Journal of Public Economics, 93, 1058-1068.

Elkington, J. (1997). Cannibals with Forks - The Triple Bottom Line of $21^{\text {st }}$ Century Business. Oxford: Capstone.

Fennell, D. \& Weaver, D. (2005). The ecotourium concept and tourism-conservation symbiosis. Journal of Sustainable Tourism, 13, 373-390.

Freitag, T. (1994). Enclave tourism development: For whom the benefits roll? Annals of Tourism Research, 21, 538-554.

Halpenny, E. (2001). Islands and coasts. In Weaver, D. (Ed.), Encyclopedia of Ecotourism. Wallingford, UK: CABI, pp. 235-250.

Høyer, K. (2000). Sustainable tourism - or sustainable mobility? Journal of Sustainable Tourism, 8, 147-161.

Hutt, D. (2016). Is China’s influence in Timor-Leste rising? The Diplomat. November 19. Accessed at http://thediplomat.com/2016/11/is-chinas-influence-in-timor-leste-rising/. Jackson, S. (2012). Small states and compliance bargaining in the WTO: An analysis of the Antigua-US Gambling Services Case. Cambridge Review of International Affairs, 25, 367-385. 
James, F. (2017). Timor-Leste island community fears large-scale tourism development on Atauro. ABC News. July 17. Accessed at http://www.abc.net.au/news/2017-0717/timor-leste-island-community-fears-tourism-development/8713414.

Jennings, G. (2010). Tourism Research. Second Edition. Milton, Australia: Wiley. Levine, S. \& Roberts, N. (2005). The constitutional structures and electoral systems of Pacific island states. Commonwealth and Comparative Politics, 43, 276-295.

Lockhart, D. (1997). Island and tourism: An overview. In D. Lockhart \& D. Drakakis-Smith (Eds.), Island Tourism: Trends and Prospects. London: Pinter, pp. 3-20.

Mangold, W. \& Faulds, D. (2009). Social media: The new hybrid element of the promotion mix. Business Horizons, 52, 357-365.

Mathieson, A. \& Wall, G. (2006). Tourism: Change, Impacts and Opportunities. Harlow: Pearson Prentice Hall.

Medina, L. (2005). Ecotourism and certification: Confronting the principles and pragmatics of socially responsible tourism. Journal of Sustainable Tourism, 13, 281-295.

Modica, P. \& Uysal, M. Eds. (2016). Sustainable Island Tourism: Seasonality, Competitiveness, and Quality-of-Life. Wallingford: CABI.

Nunkoo, R. \& Ramkissoon, H. (2010). Small island urban tourism: A residents’ perspective. Current Issues in Tourism, 13, 37-60.

Palmer, L. \& Carvalho, D. (2008). Nation building and resource management: The politics of ‘nature’ in Timor Leste. Geoforum, 39, 1321-1332.

Pearce, D. (1992). Alternative tourism: Concepts, classifications, and questions. In Smith, V. \& Eadington, W. (Eds.), Tourism Alternatives: Potentials and Problems in the Development of Tourism. Philadelphia: University of Pennsylvania Press, pp. 15-30.

Povilanskas, R. \& Armaitienè, A. (2011). Seaside resort-hinterland nexus: Palanga, Lithuania. Annals of Tourism Research, 38, 1156-1177.

Prasad, N. (2009). Small but smart: Small states in the global system. In Cooper, A. \& Shaw, T. (Eds.), The Diplomacies of Small States: Between Vulnerability and Resilience. London: Palgrave, pp. 41-64.

Rajalingam, G. (2014). 2014 Survey of Travelers to Timor-Leste. The Asia Foundation. https://asiafoundation.org/resources/pdfs/VisitorSurvey2014English.pdf.

Ribeiro, M., Valle, P., \& Silva, J. (2013). Residents’ attitudes towards tourism development in Cape Verde Islands. Tourism Geographies, 15, 654-679.

Ross, M. (2012). The Oil Curse: How Petroleum Wealth Shapes the Development of Nations. Princeton: Princeton University Press. 
Rumley, D., Forbes, V., \& Griffin, C. Eds. (2006). Australia's Arc of Instability: The Political and Cultural Dynamics of Regional Security. Dordrecht: Springer.

Salafsky, N., Cauley, H., Balachander, G., Cordes, B., Parks, J., Margoluis, C., Bhatt, S., Encarnacion, C., Russell, D., \& Margoluis, R. (2001). A systematic test of an enterprise strategy for community-based biodiversity conservation. Conservation Biology, 17, 1585-1595.

Shakeela, A. \& Weaver, D. (2012). Resident reactions to a tourism incident: Mapping a Maldivian emoscape. Annals of Tourism Research, 39, 1337-1358.

Strange, C. \& Kempa, M. (2003). Shades of dark tourism: Alcatraz and Robben Island. Annals of Tourism Research, 30, 386-405.

Timor-Leste (2011). The National Biodiversity Strategy and Action Plan of Timor-Leste (2011-2020). http://faolex.fao.org/docs/pdf/tim150856.pdf.

Timor-Leste (nd). Timor-Leste Strategic Development Plan 2011-2030. http://timorleste.gov.tl/wp-content/uploads/2011/07/Timor-Leste-Strategic-Plan-2011-20301.pdf.

Tolkach, D. (2017). History and politics of tourism in Timor-Leste. In R.W. Butler and Suntikul, W. (Eds.), Tourism and Political Change. Oxford: Goodfellow, pp. 103-120.

Tolkach, D. \& King, B. (2015). Strengthening community-based tourism in a new resourcebased island nation: Why and how? Tourism Management, 48, 386-398.

Torres, R. \& Momsen, J. (2005). Planned tourism development in Quintana Roo, Mexico: Engine for regional development or prescription for inequitable growth? Current Issues in Tourism, 8, 259-285.

Turner, L. \& Ash, J. (1975). The Golden Hordes: International Tourism and the Pleasure Periphery. London: Constable.

UNWTO (2016). Compendium of Tourism Statistics: Data 2010-2014. Madrid: World Tourism Organization.

Van Fossen, A. (2007a). Citizenship for sale: Passports of convenience from Pacific Island tax havens. Commonwealth \& Comparative Politics, 45, 138-163.

Van Fossen, A. (2007b). The struggle for recognition: Diplomatic competition between China and Taiwan in Oceania. Journal of Chinese Political Science, 12, 125-146.

Vong, M., Silva, J., \& Pinto, P. (2015). Local leaders’ perceptions about sustainable tourism development in Timor-Leste. Journal of Spatial and Organizational Dynamics, 3, 155168

Weaver, D. (1988). The evolution of a “plantation” tourism landscape on the Caribbean island of Antigua. Tijdschrift voor Economische en Sociale Geografie, 79(5), 319-331. 
Weaver, D. (1991). Alternative to mass tourism in Dominica. Annals of Tourism Research, $18,414-432$.

Weaver, D. (1998). Peripheries of the periphery: Domestic tourism involvement in Tobago and Barbuda. Annals of Tourism Research, 25(2), 292-313.

Weaver, D. (2004). Managing ecotourism in the island microstate: The case of Dominica. In Diamantis, D. (Ed.), Ecotourism: Management and Assessment. London: Thomson, pp. 151-163.

Weaver, D. (2010). Community-based tourism as strategic dead-end. Tourism Recreation Research, 35, 206-208.

Weaver, D. (2012). Organic, incremental and induced paths to sustainable mass tourism convergence. Tourism Management, 33, 1030-1037.

Weaver, D. (2013). Moving in from the margins: Experiential consumption and the pleasure core. Tourism Recreation Research, 38(1), 81-85.

Weaver, D. (2014). Asymmetrical dialectics of sustainable tourism: Toward enlightened mass tourism. Journal of Travel Research, 53 (2), 131-140.

Weaver, D. (2016). Core-periphery relationships and the sustainability paradox of small island tourism. Tourism Recreation Research. Doi:10.1080/02508281.2016.1228559.

Weaver, D. \& Lawton, L. (2014). Tourism Management. Fifth Edition. Milton: Wiley Australia.

Weaver, D. \& Lawton, L. (2017). Degrees of peripherality in the production and consumption of leisure tourism in Greenland. In Lee, Y-S., Weaver, D., \& Prebensen, N. (Eds.) Arctic Tourism Experiences: Production, Consumption \& Sustainability. Wallingford, UK: CABI, pp. 56-66.

Wood, R. (2000). Caribbean cruise tourism: Globalization at sea. Annals of Tourism Research, 27, 345-370.

Yoder, L. (2015). The development eraser: Fantastical schemes, aspirational distractions and high modern mega-events in the Oecusse enclave, Timor-Leste. Journal of Political Ecology, 22, 299-321.

Zeppel, H. (2006). Indigenous Ecotourism: Sustainable Development and Management. Wallingford, UK: CABI. 
Table 1. Small-island states and dependencies ranked by tourism contribution to GDP (where relevant data are available)

\begin{tabular}{|l|r|r|r|r|r|}
\hline Small island-state & 2014 pop. & \multicolumn{1}{c|}{$\begin{array}{c}\text { Land area } \\
\mathrm{km}^{2}\end{array}$} & $\begin{array}{c}\text { 2014 } \\
\text { stayovers }\end{array}$ & $\begin{array}{c}\text { 2014 cruise } \\
\text { arrivals }\end{array}$ & $\begin{array}{c}\text { Inbound \$ as } \\
\text { \% of GDP }\end{array}$ \\
\hline Maldives & 341.3 & 300 & $1,205.0$ & -- & ${ }^{2} 80.1$ \\
\hline Aruba & 107.4 & 180 & $1,072.0$ & 667.0 & ${ }^{1} 58.4$ \\
\hline Anguilla & 13.5 & 91 & 71.0 & 6.0 & ${ }^{1} 42.1$ \\
\hline Seychelles & 91.4 & 452 & 233.0 & 6.0 & 31.8 \\
\hline Fiji & 867.0 & 18,272 & 693.0 & 88.0 & ${ }^{2} 31.5$ \\
\hline Bahamas & 393.0 & 13,943 & $1,427.0$ & $4,805.0$ & 29.0 \\
\hline Saint Lucia & 186.0 & 616 & 338.0 & 641.0 & ${ }^{1} 26.5$ \\
\hline Antigua \& Barbuda & 86.3 & 442 & 249.0 & 519.0 & ${ }^{1} 24.9$ \\
\hline Cabo Verde & 531.2 & 4,033 & 494.0 & -- & ${ }^{3} 23.5$ \\
\hline Dominica & 71.3 & 751 & 81.0 & 287.0 & 23.4 \\
\hline Barbados & 285.0 & 430 & 521.0 & 558.0 & ${ }^{2} 22.4$ \\
\hline Jamaica & $2,723.2$ & 10,991 & $2,080.0$ & $1,424.0$ & 16.2 \\
\hline Grenada & 103.3 & 344 & 134.0 & 235.0 & ${ }^{1} 14.4$ \\
\hline Malta & 445.4 & 316 & $1,690.0$ & 472.0 & 14.4 \\
\hline Mauritius & $1,262.9$ & 2,040 & $1,039.0$ & 13.0 & 13.6 \\
\hline Saint Kitts \& Nevis & 46.2 & 261 & 113.0 & 695.0 & 13.2 \\
\hline Montserrat & 4.9 & 102 & 8.8 & -- & 13.0 \\
\hline Saint Vincent \& Gren. & 110.0 & 389 & 71.0 & 132.0 & ${ }^{1} 12.8$ \\
\hline Cyprus & 847.0 & 9,251 & $2,441.0$ & 135.0 & ${ }^{1} 12.5$ \\
\hline Tonga & 103.3 & 747 & 50.0 & -- & 9.9 \\
\hline Iceland & 332.5 & 103,000 & 998.0 & 105.0 & 8.0 \\
\hline Singapore & $5,535.0$ & 719 & $11,864.0$ & -- & 6.3 \\
\hline Bahrain & $1,404.9$ & 765 & $10,452.0$ & -- & 20.7 \\
\hline Puerto Rico & $3,474.2$ & 9,104 & $3,246.0$ & $1,209.0$ & 5.0 \\
\hline Trinidad \& Tobago & $1,349.7$ & 5,130 & 412.0 & 34.0 & ${ }^{3} 2.8$ \\
\hline Timor-Leste & $1,167.2$ & 14,874 & 60.0 & - & ${ }^{2} 0.4$ \\
\hline & & & & & 20.8 \\
\hline Average contribution & & & & & \\
\hline Source UnWO & & & & & \\
\hline
\end{tabular}

Source: UNWTO, 2016 
Figure 1. Hypothetical spatial model of tourism development in Timor-Leste

Positive market perception (experience-based social media marketing)

Physical accessibility

Trip affordability

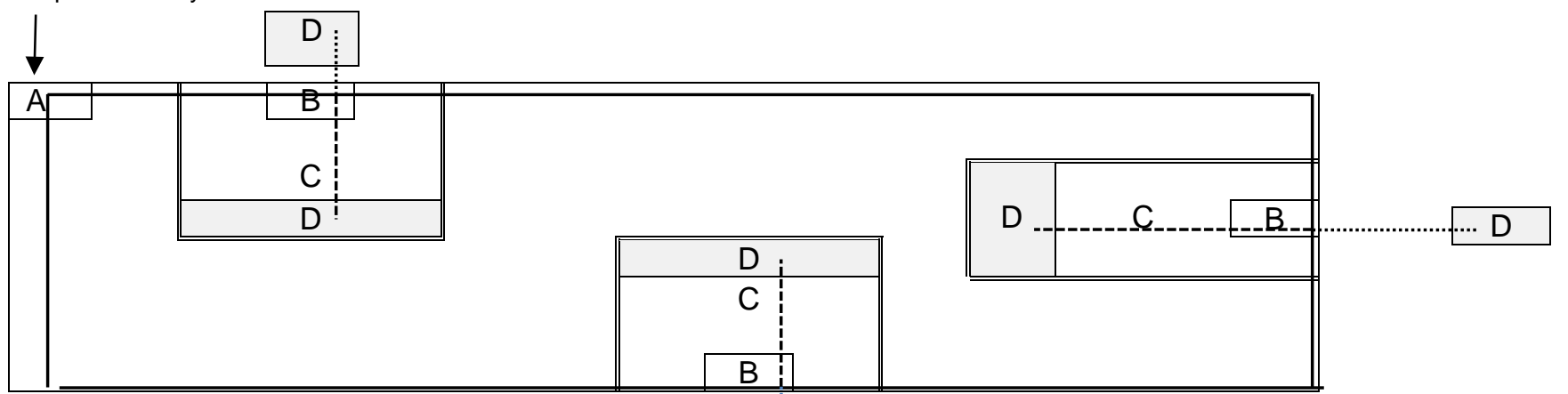

A International gateway (Dili)

D

B Beach resort growth pole (induced trajectory)

Cultural hinterland (incremental trajectory)

Tourism sub-system

D Nature-based hinterland protected area (incremental trajectory)

National trunk highway

------ Hinterland connection roads

.......... Ferry connection with marine protected area 